\title{
Evaluasi Kesiapan Modernisasi Sistem Irigasi di Daerah Irigasi Krueng Jreu Kabupaten Aceh Besar
}

\author{
Monisa Eka Yolanda ${ }^{1}$, Syahrul $^{2}$, Ichwana $^{3 *}$ \\ ${ }^{1,2,3}$ Program Studi Teknik Pertanian, Fakultas Pertanian, Universitas Syiah Kuala, Darussalam-Banda Aceh \\ ${ }^{3}$ Pusat Riset Lingkungan Hidup Universitas Syiah Kuala, Darussalam-Banda Aceh \\ *Koresponden email: ichwana_ramli@yahoo.co.id
}

Diterima: 8 Maret 2021

Disetujui: 19 Maret 2021

\begin{abstract}
Irrigation modernization is a fundamental transformation in the management of irrigation water resources which aims to increase the utilization of human resources and services provided to a farmer in an effective, efficient, and sustainable manner accordance with the five pillars of irrigation modernization. This study aims to assess the state of preparedness for the modernisation of the Krueng Jreu Irrigation Area on the basis of the five pillars of irrigation modernisation. The research methodology was an observation, interview, and research documentation. The results showed that the value of the Krueng Jreu modernization readiness index on the water supply pillars was 10 , irrigation infrastructure pillars valued at 19.8. Pillars of the system for managing irrigation with a value of 14, pillars of irrigation management institutions valued at 9 and human resource pillars for irrigation management valued at 6 . The total value of the modernization readiness indexin Krueng Jreu is 58.8 which is deemed sufficient, irrigation modernization is postponed and must be improved within 1-2 years.

Keywords: irrigation, irrigation system, modernization, modernization readiness, Krueng Jreu irrigation area

Abstrak

Modernisasi irigasi dipahami sebagai transformasi mendasar pengelolaan sumber daya air irigasi yang bertujuan untuk meningkatkan pemanfaatan sumber daya manusia dan layanan yang diberikan kepada petani secara efektif, efisien, dan berkelanjutan berdasarkan lima pilar modernisasi irigasi. Penelitian ini bertujuan untuk mengevaluasi kesiapan modernisasi Daerah Irigasi (D.I) Krueng Jreu berdasarkan 5 pilar modernisasi irigasi. Metode yang digunakan pada penelitian ini adalah observasi, wawancara, dan dokumentasi penelitian. Hasil penelitian menunjukkan nilai indeks kesiapan modernisasi di D.I Krueng Jreu pada pilar ketersediaan air dengan nilai 10, pilar prasarana irigasi dengan nilai 19,8. Untuk pilar sistem pengelolaan irigasi dengan nilai 14, pilar institusi pengelolaan irigasi dengan nilai 9 dan pilar sumber daya manusia pengelola irigasi dengan nilai 6 . Total bobot indeks kesiapan modernisasi di D.I Krueng Jreu adalah 58,8 yang dikategorikan pada predikat cukup, irigasi ditunda dan harus melakukan penyempurnaan dalam kurun waktu 1-2 tahun.
\end{abstract}

Kata Kunci : irigasi, sistem iirigasi, modernisasi, kesiapan modernisasi, D.I Krueng Jreu

\section{Pendahuluan}

Masa pengoperasian yang relatif lama serta kurangnya penanganan operasi dan pemeliharaan menyebabkan jaringan irigasi Krueng Jreu mulai tidak berfungsi dengan baik ditinjau dari indikator kinerja irigasi dengan nilai indeks kinerja sebesar 75,19 [1] serta terjadinya kekurangan air di lahan persawahan pada waktu-waktu tertentu, kehilangan air dari pintu pengambilan mencapai 25\% - 35\% sebelum sampai ke areal petakan sawah [2]. Irigasi merupakan kegiatan yang bertalian dengan usaha untuk mendapatkan air guna menunjang kegiatan pertanian seperti sawah, ladang atau perkebunan [3]. Kinerja irigasi merupakan salah satu indikasi dalam hal penggambaran pengelolaan sistem irigasi [4]. [5] penilaian kinerja jaringan irigasi tidak luput dari salah satu parameter pentingnya yaitu penilaian prasarana fisik, akan tetapi [6] menyatakan ada lima pilar yang dijadikan sebagai parameter penilaian kinerja irigasi untuk menilai tingkat modernisasi irigasi.

Modernisasi irigasi adalah suatu usaha untuk mewujudkan pengelolaan irigasi dalam rangka mendukung ketahanan pangan dengan meningkatkan layanan irigasi secara efektif, efisien dan berkelanjutan dengan meningkatkan keandalan ketersediaan air, meningkatkan prasarana irigasi, pengelolaan irigasi serta sumber daya manusianya [7]. Konsep modernisasi dipahami sebagai transformasi mendasar pengelolaan sumber daya air irigasi yang bertujuan untuk meningkatkan 
pemanfaatan sumber daya manusia dan layanan yang diberikan kepada petani [8]. Dalam modernisasi irigasi harus melakukan suatu pembaharuan yang menyeluruh baik secara manajerial, institusional, maupun secara teknikal yang juga termasuk sumber daya manusia pengelola irigasi [9]. Oleh karena itu, untuk memenuhi kebutuhan air dan mewujudkan sistem pengelolaan irigasi secara efektif dan efisien, berkelanjutan untuk pelayanan irigasi yang lebih optimal maka perlu dilakukan penelitian untuk mengevaluasi kesiapan modernisasi sistem irigasi [10] pada Daerah Irigasi (D.I) Krueng Jreu berdasarkan lima pilar modernisasi irigasi [6].

\section{Metode Penelitian}

Penelitian ini dilakukan di D.I Krueng Jreu Kecamatan Indrapuri, Kabupaten Aceh Besar, Provinsi Aceh yang dimulai dari bulan Maret sampai bulan September 2020. Penelitian dilakukan dengan cara observasi langsung ke lapangan dan wawancara dengan petugas operasi dan pemeliharaan (OP) irigasi seperti Petugas Pintu Air (PPA), kepala ranting, dan perwakilan petani.

\section{Perhitungan Nilai Indeks Kesiapan Modernisasi Irigasi (IKMI)}

Nilai indeks kesiapan modernisasi irigasi dapat dihitung dengan menganalisis lima pilar yaitu ketersediaan air, sarana dan prasarana irigasi, sistem pengelolaan, institusi pengelolaan dan sumber daya manusia [6]. Rencana modernisasi kelompok akan lebih efisien [11] dengan menganalisis IKMI Untuk mendapatkan nilai Indeks Kesiapan Modernisasi Irigasi menggunakan rumus (1).

Nilai $=\frac{\text { Bobot Upaya }}{100} \times$ Bobot Nilai

Hasil IKMI pada suatu Daerah Irigasi dapat dikategorikan dalam 4 bagian:

1. Nilai $>80$ predikat memadai: modernisasi bisa langsung diterapkan

2. Nilai 50-80 predikat cukup: modernisasi ditunda, dilakukan penyempurnaan sistem irigasi 1-2 tahun

3. Nilai < 50 predikat kurang: modernisasi ditunda, dilakukan penyempurnaan sistem irigasi 2-4 tahun

4. Nilai < 30 predikat sangat kurang: modernisasi tidak bisa dilakukan pada daerah tersebut, atau dilakukan penyempurnaan secara menyeluruh.

\section{Hasil dan Pembahasan}

\section{Keadaan Umum D.I Krueng Jreu}

D.I Krueng Jreu berlokasi di Kecamatan Indrapuri yang dapat mengaliri lahan areal seluas 3.175 Ha dalam 6 kecamatan. D.I ini berbatasan langsung dengan tiga kecamatan yaitu Kecamatan Montasik sebelah utara, Kecamatan Kuta Cot Glie sebelah timur dan Kecamatan Darul Imarah sebelah barat serta dengan Bukit Barisan sebelah Selatan [12], seperti pada Gambar 1.

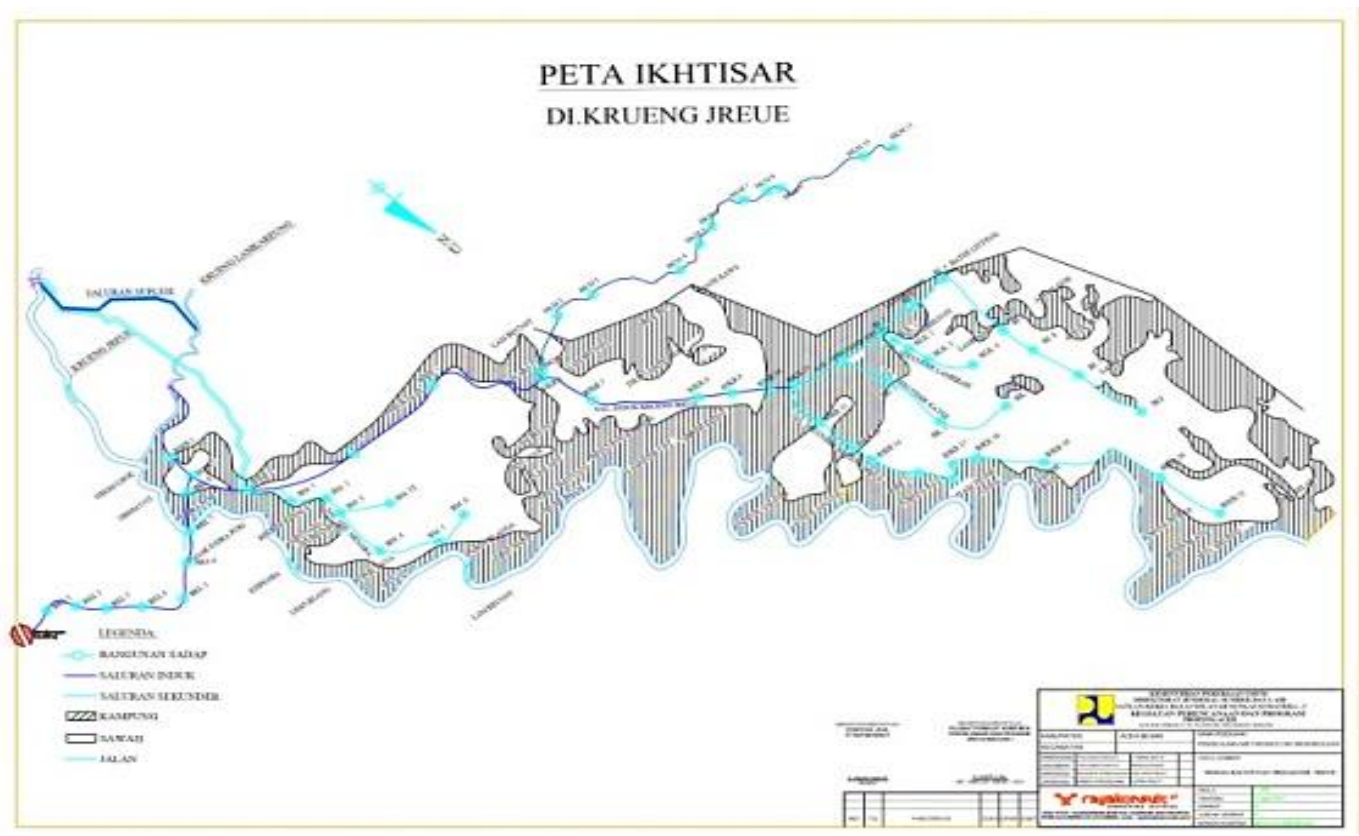

Gambar 1. Peta ikhtisar daerah penelitian Sumber : BWS 1 Sumatera (2020) 
D.I Krueng Jreu memiliki dua bangunan bendung, yaitu Bendung Krueng Jreu dan Bendung Krueng Lam Kareung. Air yang diambil dari bendung utama dialirkan ke saluran Bendung Krueng Lam Kareung yang memiliki saluran suplesi dengan saluran primer sepanjang 11,30 km dari BJKr1 hingga BJKr11 lalu ke saluran sekunder sepanjang 22,95 km terbagi atas saluran sekunder Meunara, Inong, Kayee, Lamkrah, dan Krueng Jreu kiri. Tabel 1 dan Gambar 2 memperlihatkan lebih detail mengenai D.I Krueng Jreu.

Tabel 1. Panjang saluran pada D.I Krueng Jreu

\begin{tabular}{lc}
\hline Nama Saluran & Panjang Saluran $(\mathrm{Km})$ \\
\hline Saluran Pembawa & 33.51 \\
Saluran Primer & 11.30 \\
Saluran Sekunder & 22.95 \\
\hline
\end{tabular}

Sumber: [1]

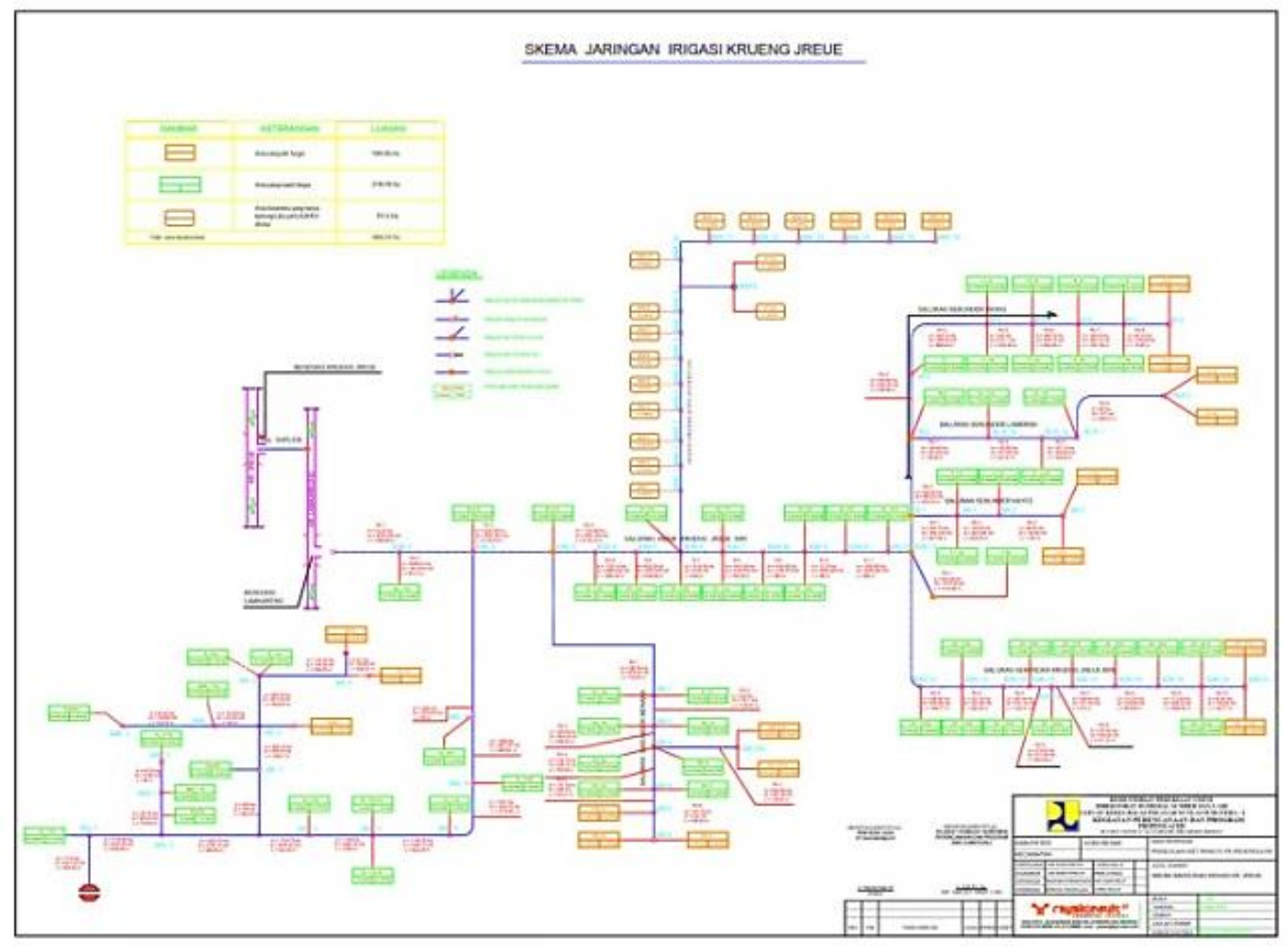

Gambar 2. Skema jaringan irigasi Krueng Jreu Sumber : BWS 1 Sumatera (2020)

\section{Indeks Kesiapan Modernisasi Irigasi}

Suatu D.I dapat dilihat kesiapannya untuk dilakukan modernisasi dengan melihat nilai bobot indeks kesiapan modernisasi irigasi berdasar lima pilar yaitu ketersediaan air, sarana dan prasarana irigasi, sistem pengelolaan, institusi pengelolaan dan sumber daya manusia.

\section{Ketersediaan Air di D.I Krueng Jreu}

Ketersediaan air pada pilar modernisasi irigasi berdasarkan Pedoman Modernisasi (2011) di D.I Krueng Jreu berdasarkan observasi langsung ke lapangan dan hasil wawancara dengan pimpinan instansi, dinas PU Pengairan cabang Indrapuri, petani di setiap kecamatan dan perangkat lainnya, tergolong predikat cukup yaitu mampu mengaliri lahan ekuivalen padi 120-200\% yang berarti hanya sampai dua kali musim tanam padi dalam satu tahun yang dapat suplai air sedangkan musim tanam tiga, debit aliran air tidak mencukupi untuk kebutuhan air irigasi dengan bobot nilai 50 dan mendapatkan nilai akhir 10 . Ketersediaan air irigasi yang kurang dapat disebabkan apabila saat pengoperasian jaringan irigasi lebih banyak mempertimbangkan faktor sosial, ketersediaan air disumber utama kurang dari perkiraan debit air yang digunakan untuk jadwal pemberian irigasi, perubahan intensitas tanam tidak sesuai dengan jadwal tanam yang sudah direncanakan [13]. 


\section{Prasarana Irigasi D.I Krueng Jreu}

Mencapai irigasi yang modern tentu harus ditunjang oleh prasarana irigasi yang memadai dan dapat memenuhi kebutuhan air irigasi. Pada bangunan utama yang termasuk bendungan utama dan pintu pengambilan dalam kondisi yang baik, sementara kantong lumpur dan pintu penguras tidak ditemukan di D.I Krueng Jreu. Untuk saluran jaringan utama 85\% dapat berfungsi dengan baik, bangunan jaringan utama $80 \%$ nya dalam kondisi bisa digunakan. Saluran pembuang atau drainase pada D.I Krueng Jreu merupakan saluran semi permanen dan kebanyakan adalah saluran tanah yang bisa kapan saja terjadi erosi dan terdapat sedimentasi sehingga saluran pembuang dalam kondisi $70 \%$ baik. Jaringan tersier berfungsi dengan baik hingga $85 \%$ dari panjang jaringan tersier yang ada. Keseluruhan bobot prasarana irigasi di D.I Krueng Jreu seperti pada Tabel 2 dan Tabel 3.

Tabel 2. Penilaian prasarana irigasi D.I Krueng Jreu

\begin{tabular}{lllllll}
\hline No & Bagian Prasarana & Bobot Upaya & Predikat & Tingkat & Bobot Nilai & Nilai \\
\hline 1. & Bangunan Utama & $15 \%$ & Sedang & $50 \mathrm{~s} / \mathrm{d} 80$ & 75 & 11,25 \\
2. & Saluran Jaringan Utama & $25 \%$ & Baik & $>80$ & 85 & 21,25 \\
3. & Bangunan Jaringan Utama & $25 \%$ & Sedang & $50 \mathrm{~s} / \mathrm{d} 80$ & 80 & 20 \\
4. & Drainase & $20 \%$ & Sedang & $50 \mathrm{~s} / \mathrm{d} 80$ & 70 & 14 \\
5. & Jaringan Tersier & $15 \%$ & Baik & $>80$ & 85 & 12,75 \\
\hline & Jumlah & & \\
\hline \multicolumn{7}{r}{ Sumber : Hasil analisis (2020) }
\end{tabular}

Tabel 3. Rekapitulasi Penilaian Prasarana Irigasi D.I Krueng Jreu

\begin{tabular}{lcccccc}
\hline \multicolumn{1}{c}{ Indikator } & $\begin{array}{c}\text { Bobot } \\
\text { Upaya }\end{array}$ & Predikat & Tingkat & Kriteria & Bobot & Nilai \\
& $25 \%$ & Cukup & $50 \mathrm{~s} / \mathrm{d} 80$ & Nilai prasarana irigasi & 79,25 \\
\hline $\begin{array}{l}\text { Prasarana } \\
\text { Irigasi }\end{array}$ & & & $50 \mathrm{~s} / \mathrm{d} 80$ & 19,8 \\
\hline Jumlah & \multicolumn{5}{c}{ Sumber : Hasil analisis (2020) }
\end{tabular}

\section{Sistem Pengelolaan Operasi dan Pemeliharaan D.I Krueng Jreu}

D.I Krueng Jreu memiliki sistem pengelolaan yang cukup dengan bobot nilai 70 karena hanya memenuhi 6 dari 10 kriteria yaitu manual OP tersedia dan dilaksanakan secara konsisten dengan mengisi seluruh blangko OP dan melaksanakannya. Di PU Pengairan Indrapuri juga sudah tersedia buku DI, BCP, Peta Ikhtisar, skema irigasi dan peta petak. Pemeliharaan jaringan dan operasi pintu tersier dilaksanakan dengan baik dan benar. Selain itu kriteria yang bisa memenuhi adalah aset manajemen sudah diterapkan pada D.I Krueng Jreu

\section{Institusi Pengelolaan D.I Krueng Jreu}

Penilaian kinerja air irigasi adalah langkah pertama untuk memastikan keberlanjutan pembangunan pertanian dan perbaikan pengelolaan air irigasi [14]. selain pemerintah sebagai pengelola, petani dan kelembagaan juga berperan dalam menjaga keberlanjutan kondisi dan fungsi aset irigasi [15]. Pengelolaan irigasi di lapangan dilaksanakan oleh Pengamat Irigasi, Juru Irigasi, Petugas Pintu Air (PPA) dan Petugas Pintu Bendung (PPB) [16]. Institusi pengelola D.I Krueng Jreu dapat dikatakan kurang dengan bobot nilai 45 dari 100 dengan nilai 9 karena hanya memenuhi 4 kriteria dari total 10 kriteria yang ada. Berdasarkan wawancara dan peninjauan ke lapangan, Instansi pengelolaan irigasi dilakukan oleh Dewan Sumber Daya Air (SDA) atau Panitia Tata Pengaturan Air (PTPA), komisi irigasi sebagai unit koordinator serta Badan Wilayah Sungai (BWS) yang mempunyai peran nyata dalam pengembangan dan pengelolaan irigasi sebagai developer atau operator.

\section{Sumber Daya Manusia di D.I Krueng Jreu}

D.I Krueng Jreu dengan sumber daya manusia tergolong kurang dengan bobot nilai 40 dan nilai 6 karena hanya memenuhi 4 dari 10 kriteria yang ada. Empat kriteria tersebut adalah dengan kuantitas pimpinan, staff dan OP yang memadai dan mempunyai jabatan fungsional dengan jumlah $>20 \%$ dari jumlah pegawai yang ada sementara yang berstatus Pegawai Negeri Sipil kurang 50\%. Perkumpulan Petani Pemakai Air (P3A) di D.I Krueng Jreu sudah kurang aktif sehingga susah untuk memberikan pelatihan kepada petani-petani yang ada, tingkat rasa kepemilikan, tanggung jawab, apresiasi dan partisipasi terhadap irigasi petani juga semakin lama semakin berkurang. Sementara jumlah petani 
sekaligus pemilik sawah $>40 \%$ dari petani yang ada serta $>20 \%$ diantaranya merupakan pemilik lahan sendiri dengan luas lebih dari 2 ha.

Lima pilar modernisasi irigasi yang dilakukan penilaian diantaranya ketersediaan air, sarana dan prasarana irigasi, sistem pengelolaan irigasi, institusi pengelola irigasi dan sumber daya manusia pengelola irigasi di D.I Krueng Jreu setelah dilakukan wawancara dan peninjauan langsung ke lapangan, dapat dilihat rekapitulasi nilainya pada Tabel 4.

Tabel 4. Rekapitulasi penilaian Indeks Modernisasi Irigasi D.I Krueng Jreu

\begin{tabular}{llccccc}
\hline \multirow{2}{*}{ No. } & \multicolumn{1}{c}{ Indikator } & $\begin{array}{c}\text { Bobot } \\
\text { Upaya }\end{array}$ & Predikat & Tingkat & $\begin{array}{c}\text { Bobot } \\
\text { Nilai }\end{array}$ & Nilai \\
\hline 1. & Ketersediaan Air & $20 \%$ & Cukup & $50 \mathrm{~s} / \mathrm{d} 80$ & 50 & 10 \\
2. & Prasarana Irigasi & $25 \%$ & Cukup & $50 \mathrm{~s} / \mathrm{d} 80$ & 79,25 & 19,8 \\
3. & Sistem Pengelolaan & $20 \%$ & Cukup & $50 \mathrm{~s} / \mathrm{d} 80$ & 70 & 14 \\
4. & Institusi Pengelolaan & $20 \%$ & Kurang & $<50$ & 45 & 9 \\
5. & Sumber Daya Manusia & $15 \%$ & Kurang & $<50$ & 40 & 6 \\
\hline \multicolumn{7}{r}{} \\
\hline
\end{tabular}

Sumber : Hasil analisis (2020)

\section{Kesiapan Modernisasi Irigasi}

Penilaian kesiapan modernisasi irigasi pada D.I Krueng Jreu berdasarkan hasil wawancara dan observasi langsung ke lapangan berdasarkan lima pilar modernisasi irigasi. Kelima pilar tersebut yaitu ketersediaan air, prasarana irigasi, sistem pengelolaan irigasi, institusi pengelola irigasi, dan sumber daya manusia maka D.I Krueng Jreu mendapat nilai 58,8. Berdasarkan Indeks Kesiapan Modernisasi Irigasi nilai tersebut tergolong ke dalam predikat cukup, modernisasi ditunda, maka harus dilakukan penyempurnaan sistem irigasi dalam kurun waktu 1-2 tahun [6].

\section{Kesimpulan}

Berdasarkan penelitian dan pembahasan tentang evaluasi kesiapan modernisasi sistem irigasi di D.I Krueng Jreu maka dapat diambil kesimpulan bahwa pilar ketersediaan air memiliki nilai IKMI 10, sarana dan prasarana irigasi memiliki nilai IKMI 19,8. Untuk pilar Sistem Pengelolaan memiliki nilai IKMI 14, pilar Institusi Pengelolaan memiliki nilai IKMI 9 dan Sumber Daya Manusia memiliki nilai IKMI 6. Total keseluruhan nilai indeks kesiapan modernisasi irigasi pada D.I Krueng Jreu adalah 58,8, berdasarkan Pedoman Modernisasi (2011) predikatnya dikatakan cukup dan harus melakukan pembenahan selama 1-2 tahun.

\section{Ucapan Terima Kasih}

Ucapan terima kasih disampaikan kepada BWS 1 Sumatera dan dinas PU Pengairan Ranting Indrapuri yang telah memfasilitasi pengambilan data penelitian. Ucapan terima kasih juga disampaikan kepada perwakilan anggota P3A, petugas OP, kepala PU Pengairan Ranting Indrapuri, penjaga pintu, dan petugas irigasi D.I Krueng Jreu selaku responden dalam pengambilan data.

\section{Singkatan}

$\begin{array}{ll}\text { D.I } & \text { Daerah Irigasi } \\ \text { IKMI } & \text { Indeks Kesiapan Modernisasi Irigasi } \\ \text { P3A } & \text { Perkumpulan Petani Pemakai Air } \\ \text { OP } & \text { Operasi dan Pemeliharaan } \\ \text { BWS } & \text { Balai Wilayah Sungai } \\ \text { SDA } & \text { Dewan Sumber Daya Air } \\ \text { PTPA } & \text { Panitia Tata Pengaturan Air } \\ \text { PU } & \text { Pekerjaan Umum } \\ \text { PPA } & \text { Petugas Pintu Air } \\ \text { PPB } & \text { Petugas Pintu Bendung } \\ \text { BCP } & \text { Buku Catatan Pemeliharaan }\end{array}$

\section{Referensi}

[1] A. Musfira, "Evaluasi Kinerja Sistem Irigasi Pada D.I Krueng Jreu Kabupaten Aceh Besar," Skripsi, Program Studi Teknik Pertanian, Universitas Syiah Kuala, Banda Aceh, 2019. 
[2] Faisal. A, Yulianu dan E, Meilianda, "Studi Peningkatan Intensitas Luas dan Pola Tanam pada D.I Krueng Jreu,” J. Arsip Rekayasa Sipil dan Perencanaan, vol. 1(3), hal. 141-149, 2018.

[3] Harianto, "Analisis penerapan sistem irigasi untuk peningkatan hasil pertanian di Kecamatan Cepu Kabupaten Blora," J. Teknik Sipil, vol. 2(1), hal. 29-34, 2018.

[4] Mulyadi, I. Soekarno, S. Natasaputra, "Penilaian Kinerja Irigasi berdasarkan Pendekatan Permen PU no.32/2007 dan Metode Masscote dengan Evaluasi Rapid Appraisal Procedure (RAP) di Daerah Irigasi Barugbug - Jawa Barat,” J. Irigasi, vol. 9, 2014.

[5] A.G. Pradipta, A.S. Pratyasta, S.S. Arif, "Analisis Kesiapan Modernisasi Daerah Irigasi Kedung Putri pada Tingkat Sekunder Menggunakan Metode K-Medoids Clustering”, Agritech, vol. 39, hal. 1-11, 2019.

[6] M. Amron, I. A. Nugroho, "Pedoman Umum Modernisasi Irigasi", Kementerian Pekerjaan Umum Direktorat Jenderal Sumber Daya Air Direktorat Irigasi Dan Rawa, Jakarta, 2011.

[7] S. Arif, A. Prabowo, "Pokok Pokok Modernisasi Irigasi Indonesia", Direktorat Jenderal Sumber Daya Air, Kementerian Pekerjaan Umum, Jakarta, 2014.

[8] A. Hakim, A. Suriadi, Masruri, "Tingkat Kesiapan Masyarakat Petani Terhadap Rencana Modernisasi Irigasi (Studi Kasus Di D.I Barugbug, Jawa Barat)", J. Sosial Ekonomi Pekerjaan Umum, vol. 4, hal. 67-78, 2012.

[9] Kementrian PUPR, Peraturan Mentri Pekerjaan Umum dan Perumahan Rakyat No 30/PRT/M/2015 tentang Pengembangan dan Pengelolaan Sistem Irigasi.Jakarta, 2015.

[10] E. Umaya, "Evaluasi Kesiapan Modernisasi Sistem Irgasi Di D.I Krueng Aceh," J. Ilmiah Mahasiswa Pertanian, vol. 4, hal. 1-10, 2019.

[11] Pramesti. D. F, M. T. Furqon dan C. Dewi, "Implementasi Metode K-Medoids Clustering Untuk Pengelompokan Data Potensi Kebakaran Hutan / Lahan Berdasarkan Persebaran Titik Panas (Hotspot)," J. Pengembangan Teknologi Informasi dan Ilmu Komputer, vol. 1, hal. 723-732, 2017.

[12] Dinas Pengairan Ranting Indrapuri, tentang Daerah Irigasi Krueng Jreu. Aceh Besar, 2020.

[13] A. A. Kunaifi, "Pola penyediaan air D.I Tibunangka dengan sumur renteng pada sistem suplesi renggung," Tesis, Universitas Brawijaya. Malang, 2011.

[14] Y. Fan, Z. Gao, S. Wang, H. Chen, J. Liu, "Evaluation of the Water Allocation and Delivery Performance of Jiamakou Irrigation Scheme, Shanxi, China," Water, 10 (654): 1-11, 2018.

[15] A. Dinar, T. Tieu, H. Huynh, "Water scarcity impacts on global food production," Global Food Security, vol. 23, hal. 212-226, 2019.

[16] Qanun Aceh No 4 Tahun 2011 Tentang Irigasi, 2011.

[17] BWS 1 Sumatera Banda Aceh, Daerah Irigasi Krueng Jreu. Banda Aceh, 2020. 